\title{
THE EU GLOBAL STRATEGY - 5 YEARS AFTER. THE APPROPRIATENESS IN FACE OF THE DYNAMIC STRATEGIC REALITIES
}

\section{INTRODUCTION}

On 28 June 2016 the European Union Global Strategy (EUGS) has been welcomed by the European Council. It comprises a new EU's approach to strategic realities in the second decade of the 21 st century. It differs significantly in its form as in its essence from the modus operandi expressed in the European Security Strategy (ESS) and in the NATO Lisbon Strategy. The issue of the obsolete ESS, outdated as a main strategic document for the CFSP and the CSDP, had been rising by many experts before the Council decided to "welcome" a new basis for these policies (e.g. Drent, Zandee, Maas, 2015: 11-13; Biscop, 2015: 4-14). Those analysts were right - the international security environment has changed drastically over the decade after its adoption. Both globally and at the European level. This transformation has therefore left, to some extent, its mark within the EUGS.

Although the "European strategic autonomy" remains an important notion in the European security discourse, as a counterbalance for the transatlantic dimension in particular, today the Global Strategy (the main EU document advocating this kind of approach) seems to be somehow forgotten as a point of reference in this regard. Studies concerning this subject (many of which the article refers to) were being published mostly in the period directly following the adoption in 2016. This is why an analysis of the EUGS essence in a bit longer run may turn out worthwhile.

The article aims to verify to what extent the EUGS content turns out to be relevant towards the Europe's evolving security environment five years after its adoption by pointing out eligible elements of the diagnosis as well as major shortcomings in this regard. To enable formulation of such conclusions the main elements of the new EU strategic concept are presented, with focus on the areas in which the EU has revaluated its approach to defining the strategic priorities and diagnosing the geostrategic environment. Subsequently, those factors are juxtaposed with the main tendencies and challenges for the EU as an actor striving for strategic homogeneity, based on their importance (or unimportance) according to the European Union Global Strategy guidelines. In this context the main research question is formulated as follows: "to what extent do the EUGS assumptions (diagnosis and postulates) keep up with the processes currently shaping the security environment of Europe?" Regarding the research problem formulated this way, any hypothesizing seems to 
be, in principle, somehow pointless taking into account the diagnostic character of this text.

The paper's considerations base on the neoliberal-institutional approach in terms of the theoretical foundations. It results mostly from the CSDP character (in spite of the EU's ambitions to become a global security actor, unachieved as yet in general) that is essentially intergovernmental as the decisive role of the member states in creation and pursuance of this policy needs to be recognized. This approach is established on the foundation of common interests, especially for international peace and stabilization, expressed and pursued by international institutions and driven by the rational choice (see more: Navari, 2008: 39-42). As the European integration process made it this far it reached also the security and defence policy issues, the EU tries to determine the common interest also in both of these domains. For the purpose of defining such collective response to the challenges of this kind, in spite of all the remaining discrepancies between the member states in this regard, the EU strategies have been formulated. Both of them aimed to strengthen the intra-EU security providers and to coordinate the member states external actions. The starting point for the considerations in the article is an approach close to Robert $\mathrm{O}$. Keohane's interpretation of a role attributed to international cooperation through multilateral institutions. Keohane classifies this phenomena as based on rational calculation of actors that seek to bring some benefits to themselves as well as on values, norms and practices underpinning such organizations (see: Keohane, 1988: 386-389). It reflects very well a dilemma concerning foundations of the EU's CSDP as this policy seems stretched between a necessity of being equipped with some instruments of hard power and the will of its certain member states to remain a "normative power" that spreads its values worldwide.

In terms of its methodological assumptions, this text is to provide some kind of a "reality check" for the EU's strategic reflection. As it refers to the documents covering such vision, the main research method employed in the study must be a critical analysis of source material. Based on that the twofold comparative study has been pursued - to illustrate the differences between those documents' substance and, therefore, to explain the shift in the EU strategic perception, as well as to confront the EU's most recent strategic concept (the state of affairs identified by the EUGS in particular) with the dynamic security environment and its evolution nowadays - both in terms of the mere diagnosis and the implementation.

\section{THE EU GLOBAL STRATEGY - THE MAIN CHARACTERISTICS}

Before analyzing the EU Global Strategy, the concept of European "strategic autonomy" (as a feature that the EU is intended to be attributed with and one of the main points of reference for the paper's considerations) is needed to be explained. It appeared for the first time (at the EU organs level) in the conclusions of the European Council adopted during the 19-20 December 2013 summit. The Council has reaffirmed a necessity for "greater responsibilities in response to those challenges if they want to contribute to maintaining peace and security through CSDP..." what "requires having the necessary means and maintaining a sufficient level of investment" 
(European Coucil, 2013: 2). In short, it means the EU's ability to act as an autonomous strategic actor - both politically (as for efficient decision-making framework) as well as in terms of the necessary assets to achieve such a state of affairs. According to the European Council the EU's "strategic autonomy" should base on three pillars: 1) effective conducting of the crisis management missions and operations, 2) the development of the civilian and military capabilities up to the level enabling to credibly pursue such tasks, 3) the achievement of sufficient standard of the European defence technological and industrial base through its integration, sustainability, novelty and competitiveness (European Coucil, 2013: 2). The concept of the EU's "strategic autonomy" means then the most significant shift when it comes to comparing the remedies offered by the EUGS and the ESS for the European security challenges.

Although it is noticeable for both the ESS and the EUGS to treat security in a very complex way, for the latter this scope seems to be much wider. The document urges to integrate and complement all accessible resources. This approach could be associated with the idea of Grand Strategy developed by Sir Basil Liddell Hart. It is possible to discover some of its elements inside the EUGS. The strategist defined the Grand Strategy as a coordination and guidance over all national resources (as well as those belonging to a union of nations) aimed at achievement of political objectives during or after a war - not only strictly military assets but also the economic/diplomatic/ industrial/human/moral ones (Liddel Hart, 1967: 362-369). The approach expressed in the EU's Global Strategy seems pretty close to this way of thinking (e.g. Barrinha, 2016: 448-450). It underlines the importance of economic, industrial, technological, diplomatic factors as well as the military and political ones. This understanding of security includes energy, cyber, political, economic dimensions besides the traditional definition of this term.

The new strategy defines directly the EU's interests, designating main areas in this regard. But first and foremost, the EUGS pays most of its attention to the issue of European (particularly intra-EU) security. This term is widely understood and different security aspects interact with each other - especially its internal and external dimension as well as different security actors. Making the EU one of them is an intention expressed within the strategy. As for defining security within the EUGS, this approach seems to be, to some extent, stretched between the "EU's Grand Strategy" formulation attempt (viewed through a realist prism with a priority for military aspects) and wide scope of the dimensions and actors as it was recognized by the Copenhagen school. But still, the military understanding of security is considered as a core in the context of resilience to both external threats and terrorist attacks inside the member states. This is the main difference from the close to "human security" concept approach expressed in the ESS.

Speaking about resilience, as Wolfgang Wagner and Rosanne Anholt (2016: 414419) indicate, this term might be considered as a keyword of the EUGS. When it comes to the security environment the strategy defines it in this context as an "ability of states and societies to reform, thus withstanding and recovering from internal and external crises" (Shared Vision, 2016: 23). Wagner and Anholt (2016: 415-416 $)$ point

${ }^{1}$ The authors notice that such an approach might be situated close to that expressed within the ESS. 
out that this term refers inter alia not only to the security concerns but also to the "soft" issues inside the member states such as their democracies (functioning of institutions and respecting the rule of law) being a condition of their security (referring to the Copenhagen understanding of political security) and a mean for stable development and prosperity.

The EUGS refers to a wide range of issues and instruments. The word "global" means there a global context of European security as well as diversity of means providing peace at the continent. It covers the EU's main interests: peace and security, prosperity, democracy and a rules-based global order (Shared Vision, 2016: 7-8). A security has been defined as the No. 1 priority of the CFSP - in its traditional military dimension but also in the context of combating asymmetric threats (especially terrorism), cyber security, energy security (security of supplies) and strategic communications. The second segment relates to the implications of situation in the security environment and it concerns such challenges as the enlargement policy (for the Balkan states and Turkey), cooperation with neighbor states and building resilience in regions surrounding Europe as well as creation of an efficient immigration policy. Lessons learned from the operations in Iraq, Libya and Afghanistan let conclude that an integrated approach to conflicts and crises regarding pre-emption activities, peacekeeping operations, resolution of armed conflicts and a synergy between humanitarian and development assistance is crucial for European security. The EU Global Strategy points out also the main areas of the CFSP external activities in its subjective ("the problematique") and objective ("the interlocutors") dimension. Moreover, the document takes into account the multilateral dimension - not only in the UN (its actions and agendas) and institutions of global financial governance (such as IMF, WTO) context but also when it comes to the emerging issues requiring a common response on this level. Realization of the principles above is to be provided by a series of quite specific means and commitments. Such tasks concern the European legislation, an acceptation of particular policy patterns (including coordination of community efforts as for diplomacy, interoperability of armed forces or economic policies of the states) and spending of budgetary resources (e.g. in the context of defence spending, development assistance or coordinated investments).

\section{A COMPARISON WITH THE ASSUMPTIONS OF THE EUROPEAN SECURITY STRATEGY AND THE NATO LISBON STRATEGY}

The EUGS proclaims a new, different approach what we may notice comparing its essence with the assumptions of the EU's previous strategic concept. This section aims to show those differences and to explain how the perception of European security has been rethought. Sven Biscop (2016a: 2-4) mentions in this context about the transition from "effective multilateralism" of the ESS to "principled pragmatism" of the EUGS. It seems to be a very brief and accurate credo of this strategic evolution.

The EU strategic approach before the EUGS used to base on understanding its international role as a "normative power." Therefore, this notion needs to be explained for further juxtaposing the former strategic document with the current one. It means 
an alternative theoretical vision of power (in contrast to the military dimension) developed, inter alia, by Hedley Bull as a notion of "civilian power" (Bull, 1982: 149-151)2 and especially by Joseph S. Nye Jr. who introduced a term of "soft power" into the discourse of international relations studies. In short, the "soft power" enables shaping beliefs and preferences of other states through the assimilation of cultural, ideological or international institutions-related patterns by them (Nye Jr., 1990: 166-167). Nye's approach might be considered as a cornerstone for the concept of the EU as a "normative power." Ian Manners distinguishes the civilian dimension of power (based on making use of the non-military instruments) from the normative one that means an "ability to shape conceptions of normal" by establishing a set principles of conduct in international relations affecting external actors either (Manners, 2002: 239-240). The Treaty on European Union (Articles 1, 1a, 2 and 10a in particular) contains a basic set of such values for the EU - including particularly promoting democracy, human rights observance and the international cooperation developed also through the multilateral institutions - as principles not only to be promoted globally but first of all to be observed by the EU institutions and the member states in their actions to set an example for others (see more: Sjursen, 2006: 236-238). This is how the EU used to see its international role before the EUGS.

The main dissimilarities between the current and the former EU strategic concept concern such elements as:

- the wider inclusion of hard power instruments within the EUGS at the expense of a normative dimension what makes a departure from the concept of EU as a normative power and an adoption of a more realistic attitude towards the contemporary security challenges (Juncos, 2016: 13-15),

- the resignation (at least partial) from the "human security" concept - the EUGS to a lesser extent takes into account such issues (called there "the global challenges") as poverty, disease, social injustice and inequalities, treated as a first step to the emergence of conflicts and instability; exploring instead the areas of armaments industry, security of energy supplies, cyber security, strategic communications, migration policies or the area of intelligence, surveillance and reconnaissance as a matter of collaboration,

- a new approach to the EU's neighborhood - more differentiated, pragmatic and less democratization-oriented, using a wider scope of means and incentives, as there is no one homogenous agenda on this cooperation as it used to be within the ESS,

- an attitude towards the use of force - while the previous strategic document, as Maria Mälksoo (2016: 379) notices, drafted the principle "don't mention the war," focusing on the normative aspects of power instead, the EUGS recognizes a crucial role of hard power (it is noticeable just by its subtitles - "secure" Europe has become "stronger" Europe) and a necessity for stronger and more powerful military instruments of the CSDP (what has been implemented e.g. by the activation of the Permanent Structured Cooperation mechanism in December 2017),

${ }^{2}$ It should be mentioned here that Hedley Bull challenged this kind of the Western Europe's role understanding in the referred article, as he suggested to increase the activity of those states in the military domain (Bull, 1982: 157-163). However, in terms of international relations theory his contribution in developing the "civilian power" concept was significant. 
- much more specified recommendations and commitments intended to achieve the aims of the document - just to mention the commitments for the member states on their military expenditures as well as the obligation to create an EU-led and financed from the common budget special fund to enhance the military capabilities of these states and to develop the European defence technological and industrial base (later materialized as the European Defence Fund; see more: Biscop, 2016b: 441-442).

However, probably the most important difference between the EUGS and the ESS relates to their legal status. While the earlier one was fully binding for the member states and it has been expressing their will about the CFSP, the new strategy has no such a nature. It is because of the preparation process. In the aforementioned conclusions of December 2013 the European Council, based on Article 18(2) of the Treaty on European Union, set a mandate for the High Representative to assess the EU strategic environment in terms of the challenges and opportunities (in cooperation with the Commission and the member states) (European Council, 2013: 4). In June 2015, the European Council reaffirmed this necessity by charging the High Representative directly with a task of preparing the relevant strategic document to be submitted until June 2016 (European Council, 2015: 5). In April 2016 the European Parliament expressed its support for the process of strategic reflection and formulated its guidelines in this regard (European Parliament, 2016). Despite these circumstances as legal foundations for the preparation works, the document has been being elaborated on closed meetings of the officials and experts, consciously unbeknown to the member states' leaders (Tocci, 2016: 462-467). For this reason the strategy binds only the EU institutions, being at the same time only guidelines for the national foreign policy-makers. That is also why the European Council only "welcomed" the EUGS, whilst the ESS has been "adopted" by this organ".

The EUGS becomes even more important as one takes into account the fact that the NATO Lisbon strategy has been adopted in 2010 when the strategic context was way different from the current realities and this document definitely requires to be comprehensively updated. That is why the Lisbon document to the lesser extent than the EUGS takes into account traditional security threats while it appreciates more such issues as the Weapon of Mass Destruction proliferation or the technology-related threats, with the new lethal types of weapons "including the development of laser weapons, electronic warfare and technologies that impede access to space" in particular (Active Engagement, 2010: 4) - the challenges somehow underestimated within the current EU strategy. On the other hand, the EUGS offers more complex understanding of security as a notion, by encompassing plenty of the soft aspects such as the political, economic and social dimension. It is as understandable as the NATO (a political-military alliance) and the EU (a highly integrated political and economic union) dispose different instruments and their strategies demonstrate it. But there are also numerous similarities between these documents - both recognize the importance of such issues as terrorism, cybersecurity, energy supplies and political cooperation with neighbor states. Nevertheless, the moment of its creation and adoption makes the EUGS the

\footnotetext{
${ }^{3}$ Compare (Brussels European Council, 2003: 21-22 and European Council, 2016: 7).
} 
most up-to-date diagnosis of the security environment for a collective security actor in the transatlantic area.

\section{THE EU GLOBAL STRATEGY TOWARDS THE CURRENT INTERNATIONAL SECURITY ENVIRONMENT - THE GLOBAL AND REGIONAL CONTEXT}

The 2 nd decade of the $21^{\text {st }}$ century significantly transformed the modus operandi in international relations. All these processes lead inter alia to the reorientation of current liberal international order towards an approach closer to power politics, weakening of international law and multilateral institutions, growing international atavisms or rise of nationalist and authoritarian tendencies inside more and more states. The desired state of affairs in this regard, according to the document, is a transformation into "a multilateral order grounded in international law, including the principles of the UN Charter and the Universal Declaration of Human Rights" (Shared Vision, 2016: 15-16) so an attempt of stopping the tendencies mentioned above. Nevertheless, the ESS accentuated a need for "an international order based on effective multilateralism," thus some kind of devaluation of the global multilateral institutions importance (especially the $\mathrm{UN}$ ) according to the EUGS is noticeable as well as the prioritization of interregional cooperation. Two main motivations in this context are as follows -1) awareness of inefficiency of the UN resulting from a deepening structural crisis of this organization over the last decade, 2) an attempt of creation an alternative for the state-based UN (from the perspective of the EU and its supranational ambitions towards Europe and, to some limited extent, the neighborhood). The EUGS, therefore, tries to keep up with the changing global order.

As for the global trends, the EUGS to some extent takes into consideration the return to power politics. It is clearly visible through a prism of attitude towards the emerging Asian powers. The document notices their growing importance and it recognizes this region as the third most important for the CFSP (below the neighborhood and the Atlantic space). The rise of Chinese and Indian power in the economic, political and military dimension as well as the long-term political proximity with Japan and South Korea and growing significance of the ASEAN member states make those strategic partnerships vital. The EUGS pays most of its attention in this regard to China what may be understandable. It is easy to notice that economic cooperation ("trade and investment") go first, before "the difficult issues" such as intellectual property rights, human rights and climate protection. It is an another sign of "the pragmatic shift" and, to some extent, a retreat from the normative approach, being as a result some kind of validation for the EU-China relations based on economic cooperation before the EUGS so in fact the resignation from the values-based approach in relations with Chinese authorities (see: Howorth, 2016: 391-392). This policy seems clearly visible considering the Comprehensive Investment Agreement concluded in December 2020 that, however, faced a lot of discordances among the EU member states - much more in terms of a potentially unequal scale of economic gains than the values (see: Moens, 2020). Its ratification has been eventually suspended in March 2021 as a sanction in 
reaction to the Uyghur genocide what in turn may be seen as the counterargument. What should also be stressed is that a transformation of the EU's position concerning regional cooperation (e.g. with African and the Middle East states) has taken place as a response to the Chinese policy in this regard which turned out to be far more efficient. The preference to cooperate pragmatically for peace, security and prosperity with external actors, over the EU values-related issues, seems a reaction to Chinese high-scale trade exchange with African states, infrastructural investments and the development assistance in this continent (see more: Davies, 2011: 188-203).

Brussels has decided to remain neutral in the Chinese-American geopolitical faceoff in its policy even before the EUGS. It seems, however, that this document underestimated a scale of the tightening confrontation over global leadership what is more and more evident as time goes by. The policy of Donald Trump in this regard ${ }^{4}$, based on the economic (especially export and investment ${ }^{5}$ ) restrictions on China and the consolidation of military power (what Chinese authorities also do, especially when it comes to the navy), had a scale unexpected by the strategy. Moreover, Joe Biden is likely to uphold most of the Trump political (though rather not rhetorical) line towards China - launching of the Quadrilateral Security Dialogue in March 2021, with India, Australia and Japan, looks like a good example of the regional counterbalancing against China. The areas of their rivalry - the markets worldwide, the South-China Sea and security of the trade routes - have not been mentioned within the EUGS. It also does not refer to a Chinese wide-range geostrategic project of the One Belt, One Road initiative. The document does not answer the question about a role for Europe in the face of this competition of superpowers what may be considered as a significant deficiency. However, it must be admitted that in the perspective of rising temperature of the American-Chinese rivalry the EU's "strategic autonomy" might turn out indispensable. The major challenge in this regard is a divergent position of the member states on a cooperation with China, including not only the aforementioned issues of the investment agreement and the Belt and Road Initiative, but also regarding the development of the 5G network and infrastructure in Europe as well as, more broadly speaking, the presence of Chinese entities on the European market (see more: Fallon, 2021).

The return to power politics means also a retreat from the values-based international order. An obstruction in the UN Security Council after the Libyan operation, Russian aggression in Ukraine, the foreign policy of Donald Trump, the reactions on the 2015 European migrant crisis or the rise of nationalist and authoritarian tendencies inside many states are just a few out of many more signs indicating this trend. The EU response is not as clear as it used to be in the ESS. On the one hand, the EUGS proposes a countervision including such standards as multilateralism, interdependencies (e.g. through economic cooperation), democracy, the rule of law, international law and observing human rights. This attitude might be recognized as naive or at least outmod-

${ }^{4}$ It is, however, necessary to notice some earlier signals of this tendency such as American objection towards the creation of the Asian Infrastructure Investment Bank in the context of the European states participating in this initiative (see: e.g. Dyer, Parker, 2015).

${ }^{5}$ Nonetheless, those tensions have been relieved to some extent by signing on 15 January 2020 the bilateral Phase One Trade Deal what enabled regrowth (though limited, in comparison to the status quo ante) of the US-China trade exchange (see: Mullen, 2021). 
ed in the moment of growing distrust towards multilateral security institutions while the EU tries to become one of such. But on the other hand, those proclaimed principles seems to be prevailed by interests and more pragmatic policy patterns from the Brussels' side. The values are not already such strong guidelines for the EU's CFSP as they used to be according to the ESS. The new attitude, though somehow hypocritical, may be interpreted as a reaction to a failure of the "normative power" concept.

The EU attractiveness on a global scale, as a power of this kind, has relatively decreased. Today the organization faces its own vital challenges to deal with. Those issues have been defined in the report delivered to the United States Congress in December 2018. The list presented there might serve as a valuable point of reference in assessing the EUGS pertinence. It encompasses:

- the departure of the United Kingdom from the EU (Brexit),

- democracy and the rule of law concerns in certain member states,

- migration and related societal integration concerns,

- increased terrorist threat,

- the aggressive policy of resurgent Russia (The European Union, 2018: 9-19).

It seems, however, that this list should be completed with another potential threat (which, for obvious reasons, would not be considered by the American analysts) resulting from emerging tensions in the US-EU relations and diminution of the NATO credibility as results of Donald Trump's presidential policy. The following paragraphs aim to verify the EUGS relevance in face of the issues above.

The political hardships over the Brexit negotiations and the rule of law concerns in certain member states may be factors strongly antagonizing the European community. These two challenges have their common core resulted from one tendency - the rise of populist, anti-establishment and anti-EU political parties and movements. Although it should not be strictly understood as a direct threat for European security, apart from the political security concept ${ }^{6}$, this issue may make an indirect impact for stability and peace at the continent. Not only their unfavorable attitude towards the EU undermines it as itself but also such elements of domestic policies as centralization of power combined with degradation of state institutions and incitement to deeper and deeper social divisions. Today it is noticeable not only in states ruled by politicians of this kind - Poland, Hungary, Slovenia, Czechia ${ }^{7}$ - but in most of the EU member states where they are a loud opposition. Their anti-EU rhetoric is often fueled by nationalism, xenophobia, misinterpreted conservatism, opposition to political mainstream (of which the EU is supposed to be a product) and, in a few cases, even by the Russian money (see: Rettman, 2017). Opinion polls all over Europe show that the support for this kind of politicians remains high. In spite of the symptoms visible already in 2016 (e.g. the situation in Hungary and Poland or the pro-Brexit campaign in the UK), the EUGS has not referred to this tendency.

In contrast, regarding the next two challenges, the EUGS has paid a lot of attention to the southern and eastern neighborhood as main areas of instability spilling over

${ }^{6}$ The Copenhagen School defines it as "organisational stability of social order(s)" (see: Buzan, Wæver, de Wilde 1998: 141).

7 Such formations participate as a part of a governmental fraction also in the UK (before 1 February 2020, obviously) and, not so long ago, Austria and Italy. 
Europe too. Indeed, plenty of essential threats for European security (mostly for the Western and Southern European countries), such as terrorism and extremism, the immigration crisis or transnational organized crime have risen because of the tensed situation in those areas. These issues are the most important challenges for the EU's border security. The wars in Syria, Yemen, Iraq or Afghanistan; the failed African states (e.g. Libya, South Sudan, Somalia, Mali) and the growing tensions in the Middle East make a significant, though indirect, impact on stability of the EU borders and internal security of its member states. The EUGS has created therefore a framework for policy towards these issues. As already mentioned, this approach is more pragmatic - resilience predominates over the values. It bases on cooperation with regional organizations, national authorities (even if undemocratic) and the local actors. The flashpoints of instability around Europe have forced the EU to change an attitude towards its neighborhood - democratization and spreading the European values gave place to building resilience and prosperity as means for stabilizing the situation. As Wagner and Anholt (2016: 3-8) indicate, the bottom-up approach, where development and prosperity are treated as conditions for peace and security, has dominated the one expressed in the ESS in which security is a precondition for development.

This conceptual reorientation has been forced by a series of events started in 2015 . Massive terrorist attacks in France (Paris 2015, Nice 2016), Germany (Berlin 2016), the United Kingdom (London and Manchester 2017), Belgium (Brussels 2016) and Spain (Barcelona 2017), conducted by terrorists affiliating themselves with the Islamic State, have proven the necessity of an integral approach to security. Moreover, Marek Madej and Marcin Terlikowski (2016: 64) indicate in this context the process of Europeanization of a terrorist threat resulted from the French authorities decision to activate the mutual assistance clause [Article 42(7) TEU] after the Parisian attacks in November 2015. Apart from the political intentions, a terrorist threat has become a common problem for all the member states, albeit there is no single, coherent and, therefore, efficient EU's immigration and asylum policy. The instruments to assure resilience inside the countries as well as impenetrability of the EU borders are necessary. This is also a conclusion of the EUGS - it points out such necessities as common work with sub-state actors on counter-radicalization, the information sharing between the member states and cooperation with regional partners in this regard.

In the context of asymmetric threats, such as terrorism exactly, in which the domestic and international dimension cannot be treated apart from each other, the coordination of the EU's military and civilian efforts becomes a particularly important challenge for the Union as a security actor. Whilst the EUGS formulates a guideline of this kind, it does not present any of more detailed plans of actions in this regard (Shared Vision, 2016, 47-48). The document issued by the Commission in 2020 entitled EU Security Union Strategy enumerates the main threats for European security as follows: organized crime, terrorism and radicalism (extremism), the critical infrastructure and public space security, cybersecurity as well as different forms of hybrid warfare (Communication, 2020, 6-19). However, this act also, same as the EU Internal Security Strategy in Action that relates to this problem in no way (Communication, 2010), does neither introduce any specific clues nor defines precisely any of suitable necessities on the discussed issue. 
Another significant circumstance is, in this context, the uncontrolled influx of immigrants, refugees and asylum seekers from the Middle East as well as from North and East Africa. It is mostly due to instable political and social situation in these regions. According to the Eurostat (Asylum, 2019), the number of asylum applications in 2015-2018 reached almost 4 million. If it was possible to include the illegal immigrants too, this number would be much higher. The downward trend in 2017 and 2018 proves importance of regional cooperation. The influx of immigrants has decelerated significantly after the EU-Turkey Statement on 18 March 2016 aimed to end the irregular migrants flow to Europe via this country. The act, even though contested over and over by the Turkish president in terms of its validity, in the context of Erdoğan's authoritarian, Islamist and sometimes even blatantly anti-European (vide the Greek-Turkish disputes over the economic zones at the Mediterranean and Aegean Sea) political line, might be seen as a symbol of the new EU's pragmatic approach to regional cooperation, expressed in the EUGS. The agreement with Turkey nearly stopped the influx from the southeastern land trail. But an inflow of illegal immigrants coming to the EU's borders by the Mediterranean Sea still remains a challenge to face. Not only as a political task but also in its humanitarian aspect as well as in the context of combating organized crime. Human trafficking and illegal smuggling of migrants to Europe through the sea threaten security of European states in many ways. Thus, the cooperation with local actors (on all levels - from organs of state to grassroots social initiatives) is required, even if those structures are very weak as it usually happens in case of failed states (e.g. Libya as the main migrants transfer point). It is necessary to mention in this context about such initiatives as the 2017 Malta Declaration (a pledge to support a Libyan government and coastguard to gain better control over the influx of immigrants through the Mediterranean Sea) or the 2017 Partnership Framework on Migration (the cooperation between the EU and governments of Ethiopia, Mali, Niger, Nigeria and Senegal for this purpose; see more: Amado Viceré, 2018: 2-5). This kind of cooperation with regional partners may be harder to achieve as the EU must act in a moment of the growing regional tensions (particularly in face of the proxy confrontation in many areas between Iran and the group of states led by Israel and Saudi Arabia) and the worsening relations with such countries as Turkey and Israel. But it is a conditio sine qua non for managing the threats coming from these regions.

When it comes to the Russian threat (the challenge No. 5) the EUGS notices a role of hybrid threats. Their scope is wide and employs both soft - cyberattacks (also as for attacks on critical infrastructure), propaganda and disinformation campaigns or economic pressure - and hard instruments such as actions of the Russian intelligence and influence agents (what became particularly important after the chemical attack on Sergei Skripal in British Salisbury on 4 March 2018) or reinforcing the Russian army arsenal and recurrent military exercises near eastern borders of the EU (Poland and the Baltic States as well as Sweden and Denmark). Brussels has defined the main challenges and the countermeasures in 2015 (see more: A Europe that protects, 2018). One of such means is the creation in 2017 (together with the NATO) of the European Centre of Excellence for Countering Hybrid Threats. It seems, however, that a threat of foreign electoral intervention, in the context of Russian actions of this kind, has been underes- 
timated within the EUGS. Though the best known case is the interference before the 2016 US Presidential Elections in favor of Donald Trump (Trump's Russia Cover-Up, 2018), it has already been proven that the Kremlin was active before the British EU membership referendum, trying to back up the "leave" voters (see e.g. Cadwalladr, 2018), and during the French presidential campaign in 2017 by supporting Marine Le Pen (see e.g. Sonne, 2018). The disinformation and psychological operations through public diplomacy tools or the medias (both traditional and social media) came in as an extremely urgent problem for the EU member states security because of the Chinese and Russian actions of this kind taken at the very beginning of the Covid-19 pandemic in Europe (see: Brovdiy, 2020: 2; EEAS Special, 2020). This occurrence has enhanced the significance of strategic communication within the EU's Common Foreign and Security Policy agenda.

As for the Crimea annexation and destabilization of Eastern Ukraine, the EUGS, though condemns these Russian actions and denies their legality, does not recognize this situation as a direct threat for security of the EU's eastern flank states. The political position over Russia (exposed on the occasion of imposing the sanctions) is also a factor antagonizing (to some extent) the member states (see: e.g. Rettman, 2018).

When it comes to the EU-US relations it needs to be stressed that the American support has been a European security anchor for many decades, also in the context of Russia (vide the NATO enlargements after the Cold War). But the presidency of Donald Trump reversed this tendency. From this perspective a crisis of the NATO, principally undermining its credibility, seems to be a major problem. Donald Trump's statements, such as the one about the obsolete NATO in its current form (Trump worries NATO, 2017) or rumors about his will to pull the US out of it (Barnes, Cooper, 2019), force to put justified questions about how responsive to an external threat is the NATO nowadays. Though the Trump appeals about more of military engagement and budgetary spending from the NATO member states were somehow legitimate and touched important issues of burden sharing and "free riding" inside the Alliance, his policy in a broader context proved that the idea of European "strategic autonomy" might become a valuable alternative. His heading for a confrontation with Europe by economic means (especially by the customs policy; Evans-Pritchard, 2019), his support for Brexit (see: Donald Trump on EU, 2016 or Kentish, 2019) and the marginalization of the pro-NATO staffers inside the presidential administration (Pilkington, Borger, 2018) were signs of a tendency which is very dangerous for Europe. The "America First" doctrine proclaimed by Trump assumed strategic self-isolation of this country, a tensed trade confrontation with China (the US biggest trade partner) and distrust towards multilateralism (both globally and regionally - vide the NAFTA, the TPP or the TTIP; see: Stephens, 2017). For Europe it has been manifested by the decision to withdraw about $1 / 3$ of the US troops stationed in Germany (suspended, however, by Joe Biden in February 2021). The EUGS suggests that the EU efforts on security might be some kind of a back-up in case of a crisis inside the NATO or American retreat from taking responsibility for European security as it used to be in the past decades. Although Donald Trump is no longer the US president, the problems in the transatlantic relations he exposed remain important points of concern for Europe. 
In the American context it is also necessary to mention about undermining of the arms control and disarmament process. The American withdrawal from the JCPOA ${ }^{8}$ (the agreement that has been presented by the EUGS as a EU's diplomatic success) and from both the INF and the Open Skies Treaty proves this tendency. Although Joe Biden sends some positive signals on this issue from the very beginning of his presidency, such as his decision to extend the New START, the Trump's policy has notably undermined credibility of American involvement in this regard (see: Smith, Eliasson, 2021). The significance of arms control and disarmament (in contrast e.g. to the 2010 NATO Lisbon strategy) has been definitely underestimated by the EUGS - not only in the context of existing regimes of this kind but also taking into account necessities to regulate this way some new, technologically advanced, categories of weaponry (e.g. lethal autonomous weapon, particularly employing the AI-driven systems).

\section{CONCLUSIONS}

The EU Global Strategy reflects the new security environment and expresses the current aspirations of the Community. Sven Biscop called this approach the "Realpolitik with European characteristics" (Biscop, 2016a: 2). Indeed, the strategy might be recognized as realist in two meanings of this word. The first one refers to realism as a paradigm in international relations theory. As already mentioned, the EUGS calls the EU to retreat from its international role of a "normative power" and suggests providing the hard power instruments as well as building the "strategic autonomy" what is typical for the neorealist understanding of international politics - even though the mere policy pattern remains close to the neoliberal-institutional approach as it concerns an international organization being, after all, a collective entity. It is a clear shift from the liberal modus operandi based on values and multilateral institutions towards the neorealist one rooted from such categories as sovereignty (if it is possible at all to talk about being sovereign within as highly integrated structure as the EU), power (military in particular) or interests. The second meaning concerns realism as a life attitude based on an assumption of dealing with reality as it is. In this context the EUGS admits that the relative power of the EU (both as an organization and as its member states) declines and it might not have sufficient instruments to promote its values around the world as a "normative power." Such symptoms as Brexit, the rise in popularity and significance of eurosceptic political parties, the worsening relations with the US, helplessness towards the situation at the EU's borders on the occasion of the migration crisis or towards Russian aggressive foreign policy and the slowdown of the European integration process constitute evidence of this tendency.

The EUGS mostly appropriately diagnoses and interprets the realities. It is expressed within the new strategy that the current global situation requires from the EU taking the matters into its own hands. And this is where an appeal for the "strategic autonomy" comes from. This pragmatism manifests as an awareness of the crisis of multilateral security arrangements and the liberal values in global dimension; as well as a necessity

8 Joint Comprehensive Plan of Action - an agreement reached between Iran and the P5+1 group, aimed to regulate the legality of Iranian actions related to the production of nuclear energy. 
to formulate a remedy - a more complex approach to regional cooperation in place of multilateralism sensu stricto, partial resignation from the normative dimension based on the democratization and human rights promotion agenda; or an aim to equip the EU with some instruments of hard power. On the other hand, more attention should be paid to the geopolitical environment and the changing nature of international order, by considering these processes to a greater extent especially when it comes to the US-China faceoff. However, the most significant limitation for practical implementation of the strategy is its legal and political status - its application remains voluntary for the member states. For this reason enforcement of its assumptions might become hard to achieve and requiring a lot of clarifications (see more: Legrand, 2016: 17-18).

Difficult to assess is the European Union on its way to become an integral strategic actor in the geopolitical dimension - the vision expressed within the EUGS may be attainable in prospect of at least the next few decades. There are plenty of limitations resulting from internal factors as well as from global trends (even if they are imperceptible nowadays) that may disrupt such expectations. However, it seems more and more visible that the European Union (the Common Security and Defence Policy) might be treated as a new sui generis approach to the collective security concept. The impasse within the United Nations Security Council as well as the changing nature of threats for European security (e.g. asymmetric or hybrid threats requiring, as a result, an indivisible approach to internal and external security) make a chance to reconceptualize this idea, while the European Union and its instruments might serve as an analytically valuable point of reference in this regard. The catalog of such mechanisms covers, among others: the mutual aid and solidarity clauses, the Schengen safeguard clauses (e.g. temporary border controls), the European Arrest Warrant, the common arms trade regulations, the Passenger Name Record base, the hotspots for refugees and migrants, the Frontex and sanctions that might be imposed on states violating international law; as it was presented by a group of the five former EU high officials in their essay (see: Vitorino et al., 2016).

In spite of such enablers, insufficient coherence as for actions taken by the EU against both military and civilian threats (within the CSDP framework and outside) remains an urgent issue. This weakness is well visible not only through a prism of the asymmetric threats (terrorist attacks in particular), connecting by their nature the military and civilian characteristics, but also in relation to non-military challenges of vital significance for European security (such as inter alia climate change, environmental pollution, all the "human security" issues and public health). Such "soft" issues might materialize into more traditional security threats, just as Richard Ullman perceived this mechanism (see: Ullman, 1983: 133-146). More integrated approach in this regard looks indispensable for the EU taking into account the nature of security problems currently. What has been revealed at full blast by the Covid-19 pandemic and its strategic implications, was rather underappreciated by the EUGS.

Josep Borrell and Thierry Breton, two senior officials of the EU, notices such a necessity in their essay (Borrell, Breton, 2020). They assume that equipping the Community with the hard power instruments is mostly to strengthen its soft power by becoming more "resilient and autonomous [...], assertive of its values, strong in its convictions, firm in its ambitions and confident of its means." Borrell and Breton point out a few challenges missed by the EUGS: defining a role for Europe towards American-Chinese geopolitical 
rivalry, protecting European capabilities in terms of the key technologies for security (not only the military ones but also critical infrastructure, crucial raw materials as well as the medical equipment and medicines) and combating the disinformation and manipulation efforts from "foreign powers." However, that is easier said than done as the progress seems quite limited in this regard. For instance, the reduction of a sum allocated to the European Defence Fund from $€ 13$ billion to $€ 8$ billion in the 2021-27 EU budget may serve as a proof for tardiness in pursuing this agenda.

In the light of the Borrell and Breton conclusions (as well as the current security threats nature) the following question seems legitimate: "would the EU even be able to remain a normative power while it needs to operate in less and less stable security environment?" Indeed, the efficiency of remaining only a normative power, with no tangible instruments to influence the global processes, in times of the liberal international order erosion and the return to power politics seems highly questionable. The other side of the coin is more and more concerns over observance of the EU fundamental principles by its certain member states (Hungary and Poland in particular) and the way it harms its credibility as a propagator of the values internationally.

\section{REFERENCES}

A Europe that Protects: Countering Hybrid Threats (2018), https://eeas.europa.eu/sites/eeas/files/ hybrid_threats_en_final.pdf (18.03.2021).

Active Engagement, Modern Defence Strategic Concept For the Defence and Security of The Members of the North Atlantic Treaty Organisation (2010), https://www.nato.int/lisbon2010/ strategic-concept-2010-eng.pdf (18.03.2021).

Amado Viceré M. G. (2018), Is the EU lost at sea? The EUGS and the implementation of a joined-up to migration, https://www.iai.it/sites/default/files/eugs_watch_5.pdf (18.03.2021).

Asylum and first time asylum applicants by citizenship, age and sex Annual aggregated data (rounded) (2019), http://appsso.eurostat.ec.europa.eu/nui/show.do?dataset=migr_asyappctza\&lang=en (18.03.2021).

Barnes J., Cooper H. (2019), Trump Discussed Pulling U.S. From NATO, Aides Say Amid New Concerns Over Russia, "The New York Times", 14.01.2019.

Barrinha A. (2016), Progressive realism and the EU's international actorness: towards a grand strategy?, "Journal of European Integration", Vol. 38, No. 4, https://doi.org/10.1080/07036337. 2016.1141905.

Biscop S. (2015), Global and Operational: A New Strategy for EU Foreign and Security Policy, https://euagenda.eu/upload/publications/untitled-12440-ea.pdf (18.03.2021).

Biscop S. (2016a), The EU Global Strategy: Realipolitik with European Characteristics, https:// www.egmontinstitute.be/content/uploads/2016/06/SPB75.pdf?type=pdf (18.03.2021).

Biscop S. (2016b), All or nothing? The EU Global Strategy and defence policy after the Brexit in "Contemporary Security Policy", Vol. 37, No. 3, https://doi.org/10.1080/13523260.2016.12 38120.

Borrell J., Breton T. (2020), For a united, resilient and sovereign Europe, https://eeas.europa.eu/ headquarters/headquarters-homepage/80567/several-outlets-united-resilient-and-sovereigneurope_sk (18.03.2021). 
Brovdiy Y. (2020), Disinformation in Times of COVID-19: Reinforcing the Responses of the European Union and the United States, "College of Europe Policy Brief", No. 5.

Brussels European Council 12 December 2003 Presidency Conclusions (2003), https://www.consilium.europa.eu/media/20825/78364.pdf (18.03.2021).

Bull H. (1982), Civilian Power Europe: A Contradiction in Terms?, "Journal of Common Market Studies", Vol. 21, No. 2, https://doi.org/10.1111/j.1468-5965.1982.tb00866.x.

Buzan B., Wæver O., de Wilde J. (1998), Security: A New Framework for Analysis, Boulder-London. Cadwalladr C. (2018), Arron Banks, Brexit and the Russia connection, "The Guardian", 16.06.2018.

Communication from the Commission to the European Parliament and the Council. The EU Internal Security Strategy in Action: Five steps towards a more secure Europe (2010), https://eur-lex. europa.eu/LexUriServ/LexUriServ.do?uri=COM:2010:0673:FIN:EN:PDF (18.03.2021).

Communication from the Commission to the European Parliament, The European Council, The Council, The European Economic and Social Committee and the Committee of the Regions on the EU Security Union Strategy (2020); https://eur-lex.europa.eu/legal-content/EN/TXT/ $\mathrm{PDF} /$ ?uri=CELEX:52020DC0605\& from=EN (18.03.2021).

Davies M. (2011), How China is Influencing Africa's Development, in: China and the European Union in Africa : partners or competitors?, (eds.) J. Men, B. Barton, Farham-Burlington.

Donald Trump on EU: 'Brexit is a good thing' (2016), https://www.bbc.com/news/av/uk-scotland-36617669/donald-trump-on-eu-brexit-is-a-good-thing (18.03.2021).

Drent M., Zandee D., Maas E. (2015), Defence matters: more urgent than ever, https://www.clingendael.org/sites/default/files/2016-02/Defence_matters_report_clingendael_apr2015.pdf (18.03.2021).

Dyer G., Parker G. (2015), US attacks UK's 'constant accommodation' with China, "Financial Times", 12.03.2015.

EEAS Special Report Update: Short Assessment of Narratives and Disinformation Around the Covid-19 Pandemic, European External Actions Service (2020), https://euvsdisinfo.eu/eeasspecial-report-update-short-assessment-of-narratives-and-disinformation-around-the-covid19-pandemic/ (18.03.2021).

European Council. 19/20 December 2013. Conclusions (2013), https://www.consilium.europa.eu/ uedocs/cms_Data/docs/pressdata/en/ec/140245.pdf(18.03.2021).

European Council meeting (25 and 26 June 2015) - Conclusions (2015), https://www.consilium. europa.eu/media/21717/euco-conclusions-25-26-june-2015.pdf (18.03.2021).

European Council meeting (28 June 2016) - Conclusions (2016), https://www.consilium.europa.eu/ media/21645/28-euco-conclusions.pdf (18.03.2021).

European Security Strategy, A Secure Europe in a Better World (2004), https:/www.cvce.eu/content/publication/2004/10/11/1df262f2-260c-486f-b414-dbf8dc112b6b/publishable_en.pdf (18.03.2021).

European Parliament resolution of 13 April 2016 on the EU in a changing global environment - a more connected, contested and complex world (2016), https://www.europarl.europa.eu/ doceo/document/TA-8-2016-0120_EN.html (18.03.2021).

Evans-Pritchard A. (2019), Trump loads the gun for car tariffs against Europe, invoking 'national security', "The Telegraph", 14.02.2019.

Fallon T. (2021), The Strategic Implications of the China-EU Investment Deal, https://thediplomat. com/2021/01/the-strategic-implications-of-the-china-eu-investment-deal/ (18.03.2021).

From Mutual Assistance to Collective Security Article 42(7) TEU: Orchestrating Our Response to New Threats (2015), https://ec.europa.eu/epsc/sites/epsc/files/strategic_note_issue_10.pdf (18.03.2021). 
Howorth J. (2016), EU Global Strategy in a changing world: Brussels' approach to the emerging powers, "Contemporary Security Policy", Vol. 37, No. 3, https://doi.org/10.1080/13523260 .2016 .1238728 .

Juncos A. (2016), Resilience as the new EU foreign policy paradigm: a pragmatist turn?, "European Security", Vol. 26, No. 1, https://doi.org/10.1080/09662839.2016.1247809.

Kentish B. (2019), Trump welcomes new UK-US deal, promising to 'very, very substantially' increase trade after Brexit, "The Independent”, 15.02.2019.

Keohane R. O. (1988), International Institutions: Two Approaches, "International Studies Quarterly", Vol. 32, No. 4, https://doi.org/10.2307/2600589.

Legrand J. (2016), Does the new EU Global Strategy deliver on security and defence, https://www. europarl.europa.eu/RegData/etudes/IDAN/2016/570472/EXPO_IDA\%282016\%29570472_ EN.pdf (18.03.2021).

Liddell Hart B. (1967), Strategy: The Indirect Approach, London.

Madej M., Terlikowski M. (2016), Wspólna Polityka Bezpieczeństwa i Obrony - Gra Pozorów, "Rocznik Strategiczny" 2015/2016, Vol. 21.

Mälksoo M. (2016), From the ESS to the EU Global Strategy: external policy, internal purpose, "Contemporary Security Policy", Vol. 37, No. 3, https://doi.org/10.1080/13523260.2016. 1238245.

Manners I. (2002), Normative Power Europe: A Contradiction in Terms?, "Journal of Common Market Studies", Vol. 40, No. 2, https://doi.org/10.1111/1468-5965.00353.

Moens B. (2020), Paris will block EU-China deal, says trade minister, https://www.politico.eu/article/paris-will-block-eu-china-deal-says-trade-minister/ (18.03.2021).

Mullen A. (2021), US-China trade war: phase one trade deal largely a 'failure', as purchases fall well short of targets, https://www.scmp.com/economy/china-economy/article/3120986/uschina-trade-war-phase-one-trade-deal-largely-failure (18.03.2021).

Navari C. (2008), Liberalism, in: Security Studies. An Introduction, (ed.) P. Williams, AbingdonOxon.

Nye Jr. J. S. (1990), Soft Power, “Foreign Policy”, No. 80, https://doi.org/10.2307/1148580.

Pilkington E., Borger J. (2018), John Bolton to replace McMaster as Trump's national security adviser, "The Guardian", 22.03.2018.

Rettman A. (2017), Illicit Russian billions pose threat to EU democracy, https://euobserver.com/ foreign/137631 (18.03.2021).

Rettman A. (2018), Italy dangles veto threat on EU's Russia sanctions, https://euobserver.com/foreign/143207 (18.03.2021).

Shared Vision, Common Action: A Stronger Europe. A Global Strategy for the European Union's Foreign and Security Policy (2016), http://eeas.europa.eu/archives/docs/top_stories/pdf/ eugs_review_web.pdf(18.03.2021).

Sjursen H. (2006), The EU as a 'normative' power: how can this be?, "Journal of European Public Policy", Vol. 13, No. 2, http://dx.doi.org/10.1080/13501760500451667.

Smith D., Eliasson J. (2021), Joe Biden's arms control ambitions are welcome-but delivering on them will not be easy, https://www.sipri.org/commentary/essay/2021/joe-bidens-arms-control-ambitions-are-welcome-delivering-them-will-not-be-easy (18.03.2021).

Sonne P. (2018), A Russian bank gave Marine Le Pen's party a loan. Then weird things began happening, "The Washington Post", 27.12.2018.

Stephens P. (2017), Trump Presidency: America First or America Alone?, "Financial Times", 16.01.2017. 
The European Union: Ongoing Challenges and Future Prospects (2018) https://crsreports.congress. gov/product/pdf/R/R44249/18 (18.03.2021).

Tocci N. (2016), The making of the EU Global Strategy, "Contemporary Security Policy", Vol. 37, No. 3, https://doi.org/10.1080/13523260.2016.1232559.

Traynor I. (2011), US defence chief blasts Europe over NATO, “The Guardian”, 10.01.2011.

Trump worries NATO with 'obsolete' comment (2017), https://www.bbc.com/news/world-us-canada-38635181 (18.03.2021).

Trump's Russia Cover-Up By the Numbers - 102 contacts with Russia-linked operatives (2018), https://themoscowproject.org/explainers/trumps-russia-cover-up-by-the-numbers-70-contactswith-russia-linked-operatives/ (18.03.2021).

Ullman R. H. (1983), Redefining Security, "International Security”, Vol. 8, No. 1, https://doi. org/10.2307/2538489.

Vitorino A., Letta E., Delors J., Lamy P., Bertoncini Y. (2016), The EU's collective security: Stronger together!, https://www.euractiv.com/section/security/opinion/the-eus-collective-securitystronger-together (18.03.2021).

Wagner W., Anholt R. (2016), Resilience as the EU Global Strategy's new leitmotif: pragmatic, problematic or promising?, "Contemporary Security Policy," Vol. 37, No. 3, https://doi.org/ $10.1080 / 13523260.2016 .1228034$.

\begin{abstract}
The objective of the article is to verify to what extent the European Union Global Strategy (EUGS) keeps up with the main global trends (at the level of international order as well as in relation to the global distribution of power) and the processes shaping the EU member states security environment of a regional scale which are perceptible from the perspective of five years following the EUGS adoption. This is also what the main research question concerns - to what extent do the diagnosis and postulates formulated inside the discussed document follow such processes in relation to the 2016-2021 period? For this reason too, the key research approach employed within the study is a critical analysis of source material.

The EU Global Strategy mostly appropriately diagnoses and interprets the realities affecting the member states security - especially when it comes to enduring processes of a global scale regarding the erosion of the liberal international order as well as the roots of possible threats for international security in its military dimension - and formulates the postulates that are pragmatic and detailed. At the same time the document underestimates some of important occurrences or even does not refer to them at all. Examples of such omissions were given in the paper.
\end{abstract}

Keywords: European Union, CFSP, CSDP, EU Global Strategy, international security environment, European security

\title{
GLOBALNA STRATEGIA UE - 5 LAT PÓŹNIEJ. ADEKWATNOŚĆ W OBLICZU DYNAMICZNYCH REALIÓW STRATEGICZNYCH
}

\section{STRESZCZENIE}

Celem niniejszego artykułu jest weryfikacja, w jakim stopniu treść Globalnej Strategii Unii Europejskiej (EUGS) obejmuje najważniejsze trendy globalne (na poziomie układu sił i porząd- 
ku międzynarodowego) oraz zjawiska kształtujące środowisko bezpieczeństwa państw członkowskich w wymiarze regionalnym, dostrzegalne w perspektywie pięciu lat od jej przyjęcia. Tego dotyczy też główne pytanie badawcze - w jakim stopniu diagnozy i postulaty zawarte w EUGS pokrywają się z tymi procesami w odniesieniu do okresu lat 2016-2021. Z tego też względu kluczowe podejście badawcze zastosowane w ramach studium to krytyczna analiza materiałów źródłowych.

Globalna Strategia UE co do zasady prawidłowo diagnozuje i interpretuje realia oddziałujące na bezpieczeństwo państw członkowskich - w szczególności w odniesieniu do niektórych procesów zachodzących w skali globalnej o trwałym charakterze, w tym erozji liberalnego porządku międzynarodowego oraz źródeł potencjalnych zagrożeń bezpieczeństwa militarnego - a zawarte w niej postulaty są pragmatyczne i zniuansowane. Jednocześnie w treści dokumentu pominięto lub potraktowano z niedostateczną uwagą pewne istotne zjawiska i okoliczności, na które wskazano w treści artykułu.

Słowa kluczowe: Unia Europejska, WPZiB, WPBiO, Globalna Strategia UE, międzynarodowe środowisko bezpieczeństwa, bezpieczeństwo europejskie 
